\title{
Persistence of insecticides used in peach orchards to larvae and adults of the predator Chrysoperla externa (Neuroptera: Chrysopidae)
}

\author{
Persistência de inseticidas utilizados em pessegueiro sobre larvas e \\ adultos do predador Chrysoperla externa (Neuroptera: Chrysopidae)
}

\author{
Rodolfo Vargas Castilhos ${ }^{1 *}$ (D), Anderson Dionei Grützmacher ${ }^{2}$ (D), \\ Leandro Rodeghiero Krüger ${ }^{2}$ (D), Paulo Ricardo Baier Siqueira² (D), Ítalo Lucas de Moraes ${ }^{2}$
}

\begin{abstract}
This work aimed to evaluate the persistence (duration of harmful activity) of five insecticides used for pest control in peach orchards, on larvae and adults of the predator Chrysoperla externa. The insecticides were sprayed on cv. Bordô vine plants using the maximum dosage recommended for peach orchards. Weekly, at 3, 10, 17, 24 and 31 days after spraying, larvae and adults of the predator were exposed to treated leaves in order to assess the residual effect of insecticides on mortality and possible effects on reproduction. Given the toxicity observed along the weekly bioassays, the insecticides were classified into persistence categories established by the International Organization for Biological and Integrated Control of Noxious Animals and Plants (IOBC). High persistence was obtained for the organophosphorus insecticides ( $\%$ of active ingredient) phosmet (0.100) and malathion (0.200), and both were considered persistent ( $>30$ days of harmful activity) to larvae and adults of $C$. externa. Similarly, the benzoylurea insecticide lufenuron (0.005), which acts exclusively on immature stages of insects, was persistent to larvae. Differences concerning the persistence for both development stages evaluated were observed for the pyrethroid insecticide deltamethrin (0.001), that was persistent to larvae but moderately persistent (16 - 30 days of harmful activity) to adults; and for the organophosphate fenthion (0.050) which was considered moderately persistent to larvae and short-lived ( $<5$ days of harmful activity) to adults of $C$. externa.
\end{abstract}

KEYWORDS: green lacewing; biological control; chemical control; integrated pest management; Prunus persica.
RESUMO: Este trabalho teve como objetivo avaliar a persistência (duração da atividade nociva) de cinco inseticidas utilizados no controle de pragas em pessegueiro, em larvas e adultos do predador Chrysoperla externa. Os inseticidas foram pulverizados em plantas de videira cv. Bordô utilizando-se a máxima dosagem recomendada para o pessegueiro. Semanalmente, aos 3, 10, 17, 24 e 31 dias após a pulverização, larvas e adultos do predador foram expostos a folhas pulverizadas para determinação do efeito residual dos inseticidas na mortalidade e possíveis efeitos na reprodução. Em função da toxicidade observada ao longo dos bioensaios semanais, os inseticidas foram classificados conforme a escala de persistência da International Organization for Biological and Integrated Control of Noxious Animals and Plants (IOBC). Alta persistência foi obtida para os inseticidas (\% de ingrediente ativo) fosmete $(0,100)$ e malationa $(0,200)$, sendo ambos considerados persistentes $(>30$ dias de ação nociva) para larvas e adultos de C. externa. De forma semelhante, o inseticida do grupo das benzoilureias, lufenurom $(0,005)$, que age exclusivamente sobre estágios imaturos de insetos, foi persistente para larvas. Diferenças quanto a persistência para ambos os estágios avaliados foi observada para o inseticida piretroide deltametrina $(0,001)$, que se mostrou persistente para larvas, porém moderadamente persistente ( 16 - 30 dias de ação nociva) para adultos; e para o organofosforado fentiona $(0,050)$, que foi considerado moderadamente persistente para larvas e de vida curta $(<5$ dias de ação nociva) para adultos de C. externa.

PALAVRAS-CHAVE: crisopídeo; controle biológico; controle químico; manejo integrado de pragas; Prunus persica. 


\section{INTRODUCTION}

The use of selective pesticides that target pest species, with minimal impact on beneficial organisms, is primordial to sustain biological control in agriculture, mostly on crops like peach, where phytophagous insects constantly occur and insecticide spraying is necessary to ensure satisfactory productivity levels.

Chemical control with broad spectrum insecticides like organophosphorus and pyrethroids is one of the most adopted pest management tactics in peach orchards, leading to suppression of natural enemies in orchards and consequently the resurgence of secondary pests that were previously kept under biological control (BOTTON et al., 2011).

The green lacewing Chrysoperla externa (Neuroptera: Chrysopidae) is a natural enemy found in many agricultural crops. This species is a polyphagous predator, and can prey upon soft-bodied arthropods from several orders (SOARES et al., 2003). As stated by SCHUBER et al. (2008), insects from Chrysopidae family are among the most abundant predators that naturally occur in peach orchards in south of Brazil, reinforcing the importance of the green lacewing for natural biological control. C. externa has potential for predation on peach orchards' pests like the aphid Brachycaudus persicae (Hemiptera: Aphididae), the European red mite Panonychus ulmi (Acari: Tetranychidae), the two-spotted spider mite Tetranychus urticae (Acari: Tetranychidae) and the white peach scale Pseudaulacaspis pentagona (Hemiptera: Diaspididae). C. externa, therefore, must be preserved whenever possible by using selective insecticides when chemical control is necessary (FREITAS, 2002). The lacewing Chrysoperla carnea (Neuroptera: Chrysopidae) is a standard test-species selected by the "International Organization for Biological and Integrated Control of Noxious Animals and Plants" (IOBC) for assessing the effect of pesticides on nontarget organisms, and it is also a relevant species considered in regulatory requirements in European Union (VOGT et al., 1998), what justifies the selection of the neotropical species C. externa for studies of pesticides' side effects.

Most of the insecticides used in peach orchards are noxious to larvae and adults of the predator $C$. externa in laboratorial tests (CASTILHOS et al., 2011a, 2011b, 2013; GRÜTZMACHER et al., 2011), however, these insecticides should not be definitely excluded from Integrated Pest Management in peach orchards since diverse factors can influence the toxicity of an active ingredient to natural enemies populations in field conditions. Therefore, subsequent tests are necessary to help establish the real impacts of these insecticides against $C$. externa (STARK et al., 2007). The Working Group "Pesticides and Beneficial Organisms" from IOBC has established a worldwide recognized sequence of tests that includes laboratorial, semi field and field evaluations, in order to stipulate pesticides toxicological parameters and determine their compatibility with biological control in Integrated Pest Management (IPM) programs.
The impact of an insecticide against a beneficial organism population is influenced by its persistence or residual toxicity. This toxicological parameter must be considered when insecticide spraying is necessary in peach orchards, as it helps to choose the most rational option and consequently preserve biological control exerted by C. externa. Due to its easy laboratorial mass rearing, $C$. externa has potential to be used in biological control programs based on releases of this predator in the field. However, the aforementioned natural enemy can be impaired by previously sprayed insecticides, and knowing the duration of harmful activity of insecticides against $C$. externa becomes significant, since such knowledge helps to schedule releases of this natural enemy in a period when it is no longer adversely affected.

Studies of insecticides' persistence against chrysopids are scarce in the literature. For Rosaceae fruit crops, GIOLO et al. (2009) conducted this kind of work for the lacewing species C. carnea which occurs mainly in North America, Europe, North Africa and Asia (CHAPMAN et al., 2006).

The number of insecticides registered for use in peach crops in Brazil is limited in comparison to other more commercially valuable crops (AGROFIT, 2017), which limits the options of peach growers for chemical pest control. Given this context, the evaluation of insecticides' selectivity to natural enemies is important in peach crops, in order to obtain precise information that can help peach growers to make the most adequate insecticide choice, or even to sustain the need of registration of new selective active ingredients. Therefore, this work aimed to evaluate the persistence (duration of harmful activity) of insecticides used in peach crops on larvae and adults of the green lacewing C. externa.

\section{MATERIAL AND METHODS}

\section{Insects and insecticides}

Larvae and adults of $C$. externa were obtained from a laboratorial colony kept under controlled conditions $\left(24 \pm 1^{\circ} \mathrm{C}, 60-70 \%\right.$ relative humidity and 14:10 light: dark cycle). Larvae were feed with Anagasta kuehniella (Lepidoptera: Pyralidae) eggs, and adults with an artificial diet, according rearing methodology described by VOGT et al. (2000).

The insecticides active ingredient [commercial product chemical group (the highest recommended dosage for peach crops in $\mathrm{g}$ or $\mathrm{mL} 100 \mathrm{~L}^{-1} / \%$ of active ingredient tested)] evaluated were: deltamethrin [Decis $25 \mathrm{EC}$ - pyrethroid (40 / 0.001)], fenthion [Lebaycid 500 - organophosphorus (100/ 0.050)], phosmet [Imidan $500 \mathrm{WP}$ - organophosphorus (200 / 0.100)], lufenuron [Match EC — benzoylurea $(100 / 0.005)]$ and malathion [Malathion $1000 \mathrm{EC}$ - organophosphorus (200 / 0.200)]. 


\section{Bioassays}

The bioassays consisted on the exposure of larvae and adults of $C$. externa to aged insecticide residues. The insecticides were sprayed at the aforementioned dosages on grapevine (IOBC standard plant due its large leaf area) plants from cv. Bordô (Vitis labrusca) with approximately $1.5 \mathrm{~m}$ high and 30 leafs, using a CO2-pressurized sprayer with a uniform flat jet nozzle. The sprayer was regulated in 50 psi pressure, and each plant received a volume of approximately $0.3 \mathrm{~L}$ until the point of drainage, assuring total plant coverage. After spray drying, plants were placed in an acclimatized greenhouse (temperature at $27 \pm 1^{\circ} \mathrm{C}$, relative humidity of $70 \pm 10 \%$, natural light incidence). Weekly, at 3, 10, 17, 24 and 31 days after spraying, treated leaves were detached from the plants and used in residual contact bioassays with larvae and adults of $C$. externa.

For larval exposure, vine leaves containing insecticide residue were placed over a methacrylate base $(34 \mathrm{~cm}$ long $\times$ $20 \mathrm{~cm}$ wide) and then superimposed by two plates $(32 \mathrm{~cm}$ long $\times 8 \mathrm{~cm}$ wide) with five holes $(5 \mathrm{~cm}$ diameter $)$ each. In each hole an exposure arena was formed by coupling a bottomless plastic cup. A single first instar larva was inserted in each arena, and feed every two days with $A$. kuehniella eggs. Four replicates with five larvae were used for each treatment in each period after spraying evaluation. Larvae were exposed to insecticides' residue on leaves until adults' emergence. In order to ensure a continuous larval exposure, the interior of the plastic cups was sprinkled with inert powder to prevent larvae from climbing the internal wall and escape from arena. The cumulative mortality caused by each insecticide was evaluated after adults' emergence, taken into account the number of adults emerged from treated larvae. The survivor adults (at least five couples) originated from treated larvae were collected to assess fecundity and fertility in reproductive bioassays. For that, adults were inserted in a transparent methacrylate cage $(15.5 \mathrm{~cm}$ high $\times 18.5 \mathrm{~cm}$ diameter) and the total amount of eggs deposited in a $24 \mathrm{~h}$ interval was collected daily during four consecutive days. The number of eggs in each collection was counted to determine the average fecundity (no. of eggs/female/day), and the eggs were then incubated in plastic trays until hatching to determine the fertility rate (percentage of hatched larvae).

For adult stage of $C$. externa, the exposure to treated leaves was trough cages formed by a methacrylate ring $(10 \mathrm{~cm}$ diameter $\times 3 \mathrm{~cm}$ high), top and bottom closed with glass plates $(12 \times$ $12 \mathrm{~cm}$ ). The methacrylate ring had 5 holes of $1.3 \mathrm{~cm}$ diameter each, closed with voile fabric to allow ventilation and an orifice with same size where an air pump 'Big-air A 420' with reverse flow was connected for suctioning toxic vapors. Treated leaves were placed between the methacrylate ring and the bottom glass plate. Four cages with 10 adults (five couples) of $C$. externa each were used for each treatment, and each cage was considered a replicate. Artificial diet (VOGT et al., 2000) and water were offered to adults, and mortality caused by insecticide residue with different ages was evaluated $120 \mathrm{~h}$ after exposure.

\section{Data analysis}

The mortality of larvae and adults exposed to treated leaves was corrected according to control (distilled water) by Schneider-Orelli's formula (PÜNTENER, 1981). In each weekly bioassay, the total effect of the insecticides for larvae was calculated by the formula: $\mathrm{E}=100 \%-(100 \%-\mathrm{M} \%) \times$ R1 $\times$ R2, where: E: total effect (\%); M\%: corrected mortality; R1: ratio between daily no. of eggs oviposited by treated and untreated females; and R2: ratio between eggs viability of treated and untreated females.

For each weekly bioassay, the insecticides were classified, based on total effect for larval stage and based on mortality at $120 \mathrm{~h}$ for adults, into four toxicity categories according to IOBC recommendation: 1 - harmless ( $<30 \%) ; 2$ - slightly harmful (30-79\%); 3 - moderately harmful (80 - 99\%); 4 - harmful (> 99\%). Persistence IOBC categories were attributed when the insecticides were harmless in two consecutive weeks or at the end of all weekly bioassays, as follows: 1 - short-lived (<5 days); 2 - slightly persistent $(5-15$ days); $3-\bmod -$ erately persistent ( $16-30$ days); 4 - persistent ( $>30$ days). Complementary statistical analyses were performed using the statistic software Winstat - Statistical Analysis System for Windows (MACHADO; CONCEIÇÃO, 2007). Data of mortality, fecundity and fertility from adults originated from exposed larvae underwent variance analysis, and the means were compared by the Tukey's test, with $\alpha=0.05$.

\section{RESULTS}

Except for fenthion, all insecticides caused high mortality to C. externa larvae in all weekly bioassays (Table 1 ). The insecticides phosmet and lufenuron caused $100 \%$ mortality on larvae and were harmful at 3,10,17, 24 and 31 days after spraying (DAS). Deltamethrin and malathion induced 100\% mortality on larvae until 10 and 17 DAS, respectively, and were moderately harmful on the subsequent periods. Larval mortality caused by fenthion was significant only at 3,10 and 17 DAS, while at 24 and 31 DAS mortality was similar to control, being this insecticide considered harmless since 24 DAS.

The total effect of phosmet and lufenuron on larvae was $100 \%$ in all DAS (Fig. 1A), and both insecticides were persistent (category 4) against C. externa larvae (Table 1). Deltamethrin and malathion were also persistent (category 4) to larvae with a mean total effect of 95.61 and $92.51 \%$, respectively (Fig. 1A). The total effect of fenthion on larvae was higher than $30 \%$ up to 17 DAS, being therefore classified as moderately persistent (category 3 ) (Table 1).

The survival of larvae exposed to fenthion residues at 17, 24 and 31 DAS made possible to evaluate reproductive parameters of adults. Fecundity of females originated from exposed larvae was lower than control on the three aforementioned 
periods; however, significant difference was observed only at 31 DAS, with higher reduction in reproductive potential (RPR) (Table 2). Fertility of females originated from larvae treated with fenthion was similar to control in all DAS evaluated, with no significant difference observed.

For C. externa adults, phosmet and malathion caused significant mortality at 3,10,17, 24 and 31 DAS, and were consequently considered persistent (category 4) (Table 1). The mortality rate induced by these insecticides was higher than $90 \%$ up to 31 DAS (Fig. 1B). Differently, mortality by deltamethrin decayed from 85 to $10 \%$ along the bioassays (Fig. 1B), and this insecticide was considered harmless at 10 , 24 and 31 DAS, being then moderately persistent to adults (category 3) (Table 1). Fenthion killed $100 \%$ of adults at

Table 1. Mortality ( $\mathrm{n} \pm \mathrm{SE}$ ) of larvae and adults of Chrsysoperla externa at 3, 10, 17, 24 and 31 days after spraying, and Integrated Control of Noxious Animals and Plants categories.

\begin{tabular}{|c|c|c|c|c|c|c|c|c|c|c|c|c|c|}
\hline \multirow{3}{*}{ Treatment } & \multicolumn{11}{|c|}{ Days after spraying } & \multirow{2}{*}{\multicolumn{2}{|c|}{ Persistence }} \\
\hline & \multirow{2}{*}{ R.D $\mathbf{D}^{(1)}$} & \multicolumn{2}{|l|}{3} & \multicolumn{2}{|l|}{10} & \multicolumn{2}{|l|}{17} & \multirow{2}{*}{$\begin{array}{r}24 \\
n^{\circ} \text { dead }\end{array}$} & \multicolumn{3}{|c|}{31} & & \\
\hline & & $n^{\circ}$ dead $^{(2)}$ & $C^{(3)}$ & $n^{\circ}$ dead & C & $\mathrm{n}^{\circ}$ dead & C & & C & $n^{\circ}$ dead & C & Days & $\mathrm{C}^{(4)}$ \\
\hline \multicolumn{14}{|l|}{ Larvae } \\
\hline Control & - & $0.25 \pm 0.25 b$ & - & $0.75 \pm 0.48 c$ & - & $0.75 \pm 0.25 b$ & - & $0.50 \pm 0.29 b$ & - & $0.25 \pm 0.25 b$ & - & - & - \\
\hline Deltamethrin & 40 & $5.00 \pm 0.00 a$ & 4 & $5.00 \pm 0.00 a$ & 4 & $4.75 \pm 0.25 a$ & 3 & $4.75 \pm 0.25 a$ & 3 & $4.50 \pm 0.29 a$ & 3 & $>30$ & 4 \\
\hline Fenthion & 100 & $5.00 \pm 0.00 a$ & 4 & $2.75 \pm 0.75 b$ & 2 & $1.75 \pm 0.75 b$ & 2 & $0.75 \pm 0.25 b$ & 1 & $0.25 \pm 0.25 b$ & 1 & $16-30$ & 3 \\
\hline Phosmet & 200 & $5.00 \pm 0.00 a$ & 4 & $5.00 \pm 0.00 a$ & 4 & $5.00 \pm 0.00 a$ & 4 & $5.00 \pm 0.00 a$ & 4 & $5.00 \pm 0.00 a$ & 4 & $>30$ & 4 \\
\hline Lufenuron & 100 & $5.00 \pm 0.00 a$ & 4 & $5.00 \pm 0.00 a$ & 4 & $5.00 \pm 0.00 \mathrm{a}$ & 4 & $5.00 \pm 0.00 a$ & 4 & $5.00 \pm 0.00 a$ & 4 & $>30$ & 4 \\
\hline Malathion & 200 & $5.00 \pm 0.00 a$ & 4 & $5.00 \pm 0.00 a$ & 4 & $5.00 \pm 0.00 a$ & 4 & $4.50 \pm 0.50 a$ & 3 & $3.75 \pm 0.63 a$ & 3 & $>30$ & 4 \\
\hline \multicolumn{14}{|l|}{ Adults } \\
\hline Control & - & $0.00 \pm 0.00 c$ & - & $0.25 \pm 0.25 b$ & - & $0.00 \pm 0.00 c$ & - & $0.00 \pm 0.00 \mathrm{~b}$ & - & $0.00 \pm 0.00 \mathrm{~b}$ & - & - & - \\
\hline Deltamethrin & 40 & $8.50 \pm 0.65 b$ & 3 & $3.00 \pm 0.71 b$ & 1 & $3.00 \pm 0.71 b$ & 2 & $1.25 \pm 0.48 b$ & 1 & $1.00 \pm 0.00 \mathrm{~b}$ & 1 & $16-30$ & 3 \\
\hline Fenthion & 100 & $10.00 \pm 0.00 a$ & 4 & $3.00 \pm 2.38 b$ & 1 & $2.00 \pm 0.41 b$ & 1 & - & - & - & - & $<5$ & 1 \\
\hline Phosmet & 200 & $10.00 \pm 0.00 a$ & 4 & $10.00 \pm 0.00 a$ & 4 & $9.50 \pm 0.50 a$ & 3 & $9.25 \pm 0.48 a$ & 3 & $9.50 \pm 0.50 a$ & 3 & $>30$ & 4 \\
\hline Malathion & 200 & $10.00 \pm 0.00 a$ & 4 & $10.00 \pm 0.00 \mathrm{a}$ & 4 & $10.00 \pm 0.00 \mathrm{a}$ & 4 & $10.00 \pm 0.00 \mathrm{a}$ & 4 & $10.00 \pm 0.00 a$ & 4 & $>30$ & 4 \\
\hline
\end{tabular}

${ }^{(1)}$ R.D: recommended dosage ( $\mathrm{g}$ or $\mathrm{mL} .100 \mathrm{~L}^{-1}$ ); (2)larvae: mean number of four replicates with five insects each; adults: mean number of four replicates with ten insects each. Means followed by the different letter in columns differ significantly by the Tukey's test at $5 \%$ probability. Larvae: 3 DAS (df = 5,18; F = 361; $p<0.05), 10$ DAS (df = 5,18; F = 24.38; $<<0.05), 17$ DAS (df = 5,18; F = 14.94; $p<0.05), 24$ DAS (df = 5, 18; $F=61.74 ; p<0.05), 31$ DAS (df = 5,18; $F=51.33 ; p<0.05) ;$ adults: 3 DAS $(d f=4,15 ; F=227.4 ; p<0.05), 10$ DAS $(d f=4,15 ; F=16.10 ; p<0.05), 17$ DAS (df = 4,15; $F=138.67 ; p<0.05), 24$ DAS $(d f=4,15 ; F=109.41 ; p<0.05), 31$ DAS $(d f=4,15 ;$ $\mathrm{F}=507.67 ; \mathrm{p}<0.05) ;{ }^{(3)} \mathrm{IOBC}$ toxicity categories: 1 = harmless (<30\%), 2 = slightly harmful $(30-79 \%), 3=$ moderately harmful $(80-99 \%)$, 4 = harmful (>99\%); ${ }^{(4)}$ IOBC persistence categories: 1 = short-lived (< 5 days), 2 = slightly persistent $(5-15$ days), $3=$ moderately persistent ( $16-30$ days), 4 = persistent (> 30 days).

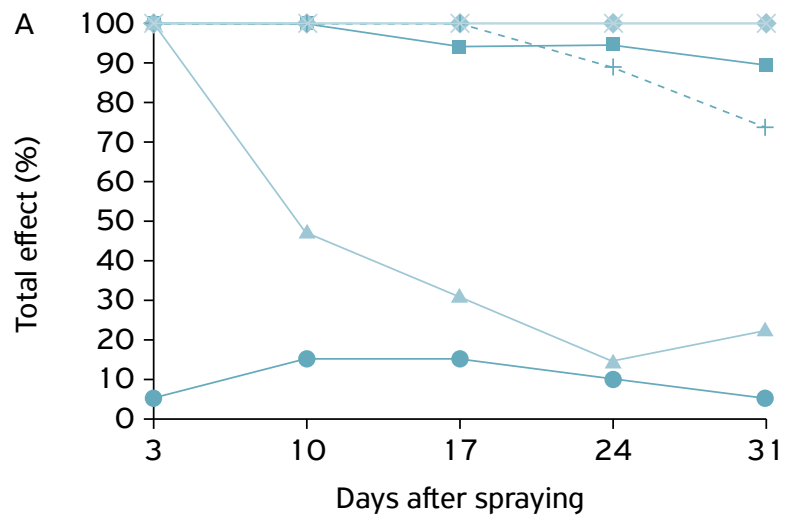

- Deltamethrin $\longrightarrow$ Phosmet

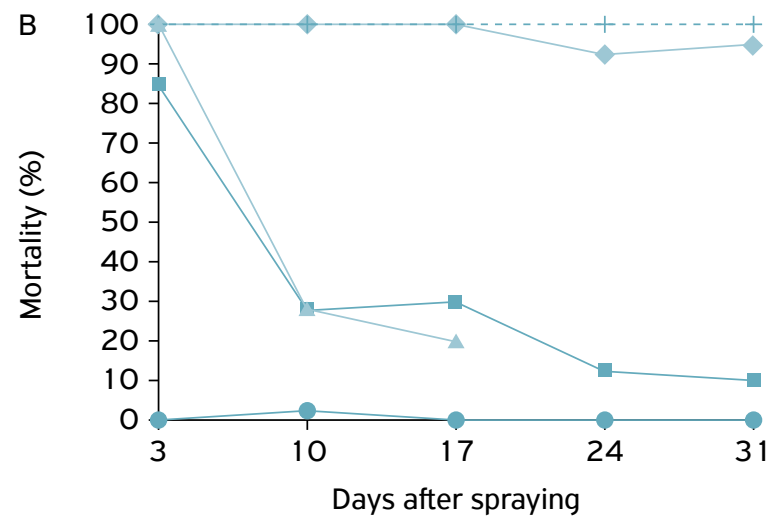

Days after spraying

Figure 1. Residual toxicity of insecticides against Chrysoperla externa: Total effect on larvae (A) and mortality of adults (B) in different intervals after spraying. 
3 DAS, but it was harmless at 10 and 17 DAS since it killed less than $30 \%$ of adults at these periods. Given this context, fenthion was considered short-lived (category 1) to C. externa adults (Table 1).

\section{DISCUSSION}

Results from our study with the organophosphorus phosmet are in agreement with GIOLO et al. (2009), which classified this active ingredient as persistent to adults of the green lacewing C. carnea. Similarly, high toxicity and residual activity of phosmet to predators was reported by ROUBOS et al. (2014), who observed toxic effects against the insidious flower bug Orius insidiosus (Hemiptera: Anthocoridae), the green lacewing Chrysoperla rufilabris (Neuroptera: Chrysopidae) and the lady beetle Hippodamia convergens (Coleoptera: Coccinelidae) after exposure to residues aged up to 14 days. Phosmet persistence is also reported for parasitoids. The egg's parasitoid T. pretiosum was susceptible to residues of this pesticide after 31 days from spraying in vine leafs (NÖRNBERG et al., 2011). Also, BELOTI et al. (2017) classified the organophosphorus phosmet as moderately persistent (class 3 ) and malathion as slightly persistent (class 2) for the parasitoid specie Tamarixia radiata (Hymenoptera: Eulophidae). In our study, malathion proved to be persistent to the predator $C$. externa, but different persistence levels were found for parasitoids of the genus Trichogramma. According to GIOLO et al. (2008), malathion was categorized as moderately persistent to $T$. pretiosum using the same concentration used in our study.

On the whole, insecticides from organophosphorus chemical group are broad spectrum and persistent to natural enemies. As reported by VANACLOCHA et al. (2013), the organophosphorus chlorpyrifos was noxious and persistent against the parasitoid Aphytis melinus (Hymenoptera: Aphelinidae), to whom it caused significant mortality rates for more than 28 days. The same insecticide was considered moderately persistent to the parasitoid T. pretiosum (16 - 30 days) when sprayed on vine leafs (STEFANELLO JÚNIOR et al., 2012). GRÜTZMACHER et al. (2004) also reported long duration of organophosphorus toxicity against T. cacoeciae, and classified fenthion and trichlorfon as persistent to adults of the mentioned parasitoid. Based on our findings (Table 1), the spray of phosmet and malathion should be avoided whenever possible in peach orchards where $C$. externa naturally occurs or is released, once the high mortality and persistence against larvae and adults induced by these active ingredients impair the predatory potential and the recolonization of this natural enemy in treated areas.

The insecticide fenthion also belongs to the organophosphorus chemical group, and it was the less persistent among the tested insecticides in our study. The duration of fenthion harmful activity was higher for larvae (16-30 days) in comparison to adults ( 5 days) (Table 1 ), which highlights the difference in susceptibility between these two development stages. Even though adults of $C$. externa don't exert predation, this life stage is critical for colonization and spread of biological control across peach crops.

Despite the low mortality from 17 DAP, the reproductive potential of adults originated from larvae exposed to fenthion residues was slightly reduced from 17 to 31 DAP (Table 2). Sublethal effects on reproduction must be considered in IPM paradigms, since it can affect the establishment of predator's population in agroecosystems (BIONDI et al., 2012). A great number of laboratorial studies are focused exclusively on pesticide acute toxicity to natural enemies. However, pesticides may induce sublethal effects on exposed individuals that may negatively impact the population dynamics of natural enemies and impair their beneficial activity, what consequently compromise the efficacy of IPM programs in which biological control is involved (DESNEUX et al., 2007).

Low persistence of an organophosphorus insecticide was also reported by RUIZ; MORAES (2008), which verified low residual toxicity of azinphos-methyl against the predatory mite Neoseilus californicus (Acari: Phytoseiidae). According to HEUER et al. (1976), organophosphorus insecticides are degraded by phosphatase enzymes and its persistence in nature can be influenced by the molecule's propensity for degradation. In field, one of the main triggers of organophosphorus environmental degradation is the photolysis caused by sunlight irradiation (KRALJ et al., 2007). Given this context, the lower persistence of fenthion against C. externa in comparison to other organophosphorus evaluated in our study may be related to its higher propensity for enzymatic or photodegradation.

Table 2. Sublethal effect of fenthion on fecundity (eggs/ female/day), fertility (\% hatching), and consequent reduction on reproductive potential of Chrysoperla externa.

\begin{tabular}{|c|c|c|c|}
\hline Treatment & Fecundity $^{(1)}$ & Fertility ${ }^{(1)}$ & RPR $(\%)^{(2)}$ \\
\hline \multicolumn{4}{|c|}{17 days after spraying } \\
\hline Control & $25.18 \pm 2.29 a$ & $92.05 \pm 1.44 \mathrm{a}$ & - \\
\hline Fenthion & $22.76 \pm 3.11 \mathrm{a}$ & $92.20 \pm 2.78 \mathrm{a}$ & 9.4 \\
\hline \multicolumn{4}{|c|}{24 days after spraying } \\
\hline Control & $30.79 \pm 2.44 a$ & $85.75 \pm 4.59 a$ & - \\
\hline Fenthion & $27.75 \pm 4.64 \mathrm{a}$ & $85.62 \pm 5.20 \mathrm{a}$ & 10.04 \\
\hline \multicolumn{4}{|c|}{31 days after spraying } \\
\hline Control & $24.86 \pm 2.87 a$ & $83.30 \pm 4.94 a$ & - \\
\hline Fenthion & $20.00 \pm 2.21 b$ & $80.67 \pm 4.25 a$ & 22.09 \\
\hline
\end{tabular}

(1)Means followed by the same letter in columns don't differ significantly by the Tukey's test at $5 \%$ probability. Fecundity: 17 DAS (df = 1,6; $F=2.55 ; p=0.17) ; 24$ DAS (df = 1,6; $F=1.43$; $\mathrm{p}=0.29$ ); 31 DAS (df $=1,6 ; \mathrm{F}=7.19 ; \mathrm{p}=0.036$ ); Fertility: 17 DAS $(\mathrm{df}=1,6 ; \mathrm{F}=0.0098 ; \mathrm{p}=0.92) ; 24 \mathrm{DAS}(\mathrm{df}=1,6 ; \mathrm{F}=0.0015$; $\mathrm{p}=0.97) ; 31 \mathrm{DAS}(\mathrm{df}=1,6 ; \mathrm{F}=0.65 ; \mathrm{p}=0.45) ;{ }^{(2)} \mathrm{RPR}$ : reduction on reproductive potential = $1-(R 1 \times R 2) \times 100$, where: $R 1=$ ratio between fecundity in fenthion and control and $\mathrm{R} 2$ = ratio between fertility in fenthion and control. 
The short life of fenthion for $C$. externa adults is relevant for the success of biological control in previously treated areas, as it allows the re-entry of adults from untreated areas and the survival of emerged adults post spraying, as well as the survival of mass released adults in an augmentative biological control.

Temperature also plays an important role on insecticide effectiveness and can influence its persistence against predators. As described by MANSOOR et al. (2015), organophosphorus have a positive temperature coefficient, that is, become more toxic with the increase in temperature, whereas pyrethroids have negative coefficient, and perform better at lower temperatures. According to the mentioned authors, the toxicity of organophosphorus chlorpyrifos against the green lacewing C. carnea increased 1.79 fold from 20 to $40^{\circ} \mathrm{C}$, while toxicity from the pyrethorid lambda cyhalothrin decreased 2.15 fold.

Deltamethrin persistent profile for predators was also described by PEKAR; BENES (2008), who verified that 20 days old residues induced significant mortality on the predatory spiders Pardosa palustris (Aranae: Lycosidae), Philodromus cespitum (Aranae: Philodromidae) and Theridion impressum (Aranae: Theridiidae). Synthetic pyrethroids are more stable compounds in comparison with natural pyrethrins, and are characterized by its long residual activity (PALMQUIST et al., 2012). Notwithstanding, some studies have reported low persistence of deltamethrin to natural enemies. The aforementioned active ingredient was quickly degraded, and considered short-lived for $C$. carnea in the absence and presence of artificial rainfall in greenhouse conditions (MAIA et al., 2016). According to DESNEUX et al. (2005), only $10 \%$ of deltamethrin residues were detected on colza leafs after two days from spraying, and after seven and 14 days from spraying, a minimum amount was found; being this insecticide harmless to the aphid parasitoid Diaeretiella rapae (Hymenoptera: Braconidae) when released in treated fields. As reported by SILVA; OLIVEIRA (2007), deltamethrin residues sprayed on citrus leafs in an equivalent dosage from our study didn't induce significant mortality in adults of the predatory mite $N$. californicus. These findings show that the persistence of this active ingredient against beneficial insects varies according to factors like the vegetal material, susceptibility of the natural enemy species, dosage and temperature.

The insecticide lufenuron, from the benzoylurea chemical group, acts in the molting process by inhibiting chitin biosynthesis, an essential component for the formation of the new exoskeleton, and thus prevents normal metamorphosis of immature stages (TUNAZ; UYGUN, 2004). As the molting process only occur on larval stage, the evaluation of lufenuron persistence against the adult stage of $C$. externa was unnecessary in face of the harmlessness of this insecticide against adults (CASTILHOS et al., 2011b). Lufenuron is commonly named as an 'insect growth regulator' (IGR) insecticide, and despite being considered more ecofriendly in comparison to neurotoxic compounds, its toxicity against $C$. externa larvae was considered persistent (> 30 days) (Table 1$)$. Accordingly, lufenuron spray is detrimental to C. externa population in orchards, especially when larvae are predominant in the lacewing population. The high persistence of lufenuron for larvae in our study is in agreement with results obtained from VAN DE VEIRE et al. (2002), that reported mortality rates ranging from 75.6 to $100 \%$ for nymphs of the predatory bug Orius laevigatus (Hemiptera: Anthocoridae) exposed to $5,10,15$ and 30 days old lufenuron residues. Also considered an IGR insecticide, methoxyfenozide was toxic to larvae of the predatory beetle Stethorus punctillum (Coleoptera: Coccinellidae) for 7 days (NIENSTEDT; MILES, 2008), evidencing that toxicity of IGRs on larvae and nymphs of predators can persist for a considerable time after spraying.

It should be noted that in our study plants were placed in an acclimatized greenhouse after spraying, and were not exposed to environmental conditions like rainfall, temperature and humidity gradient, and other climatic factors that may influence pesticides persistence in the environment (ZONGMAO; HAIBIN, 1997).

The persistence of pesticides is often unvalued in selectivity studies. However, it must be considered, since information about the duration of toxicity allows a more precise judgment on the impact of pesticides to beneficial organisms and helps to estimate the survival of natural enemies' population after exposure to chemical control. As a result of the limited offer of new chemical molecules and demand for a more sustainable and environmentally friendly agriculture, the applied biological control is in continuous advance in Brazil (PARRA; COELHO JUNIOR, 2019). However, peach growers still depend on insecticides for controlling primary pests in orchards, and for a successful applied biological control with $C$. externa, subsequent inundative releases of this predator must be scheduled to occur afterwards the persistence interval. By preserving natural enemies such as $C$. externa, the biological control exerted by this predator can help on the suppression of secondary pests and consequently on the decrease of insecticide use in peach orchards.

\section{CONCLUSIONS}

The insecticides (\% of active ingredient) deltamethrin (0.001), phosmet (0.100), malathion (0.200) and lufenuron (0.005) were persistent ( $>30$ days of harmfulness), while fenthion $(0.050)$ was moderately persistent $(16-30$ days of harmfulness) for $C$. externa larvae. For adults, phosmet $(0.100)$ and malathion $(0.200)$ were persistent, deltamethrin $(0,001)$ was moderately persistent and fenthion was short-lived $(<5$ days of harmfulness). Since all insecticides evaluated showed persistence to the larval stage, subsequent field (peach orchards) trials are recommended to obtain more information about the real impact of these insecticides against $C$. externa. 


\section{FUNDING}

This study was financed in part by the Coordenação de Aperfeiçoamento de Pessoal de Nível Superior - Brasil
(CAPES) Finance Code 001. Research Support Foundation of the State of Rio Grande do Sul (FAPERGS) and National Council for Scientific and Technological Development (CNPq) for financial support.

| || | | | | | | | | | | | | | | | | | | | | | | | | | | | | | | | | | | | | | | | | | | | | | | | | | | | | | | | | | | | | | | | | | | | | | | | | | | | | | | | | | | | | | | | | | | | | | | | | | | | | | | | | | | | | | | | | | | | | | | | | | | | | | | | | | | | | | | | | | | | | | | | | | | | | | | | | | | | | | | | | | | | | | | | | | | | | | | | | | | | | | | | | | | | | | | | | | | | | | | | || || REFERENCES

BELOTI, V.H.; ALVES, G.R.; MORAL, R.A.; DEMÉTRIO, C.G.B.; YAMAMOTO, P.T. Acute toxicity of fresh and aged residues of pesticides to the parasitoid Tamarixia radiata and to the HLB-bacteria vector Diaphorina citri. Neotropical Entomology, Londrina, v.47, n.3, p.1-9, 2017. https://doi.org/10.1007/s13744-017-0575-2

BIONDI, A.; DESNEUX, N.; SISCARO, G.; ZAPPALÀ L. Using organic-certified rather than synthetic pesticides may not be safer for biological control agents: Selectivity and side effects of 14 pesticides on the predator Orius laevigatus. Chemosphere, Amsterdam, v.87, n.7, p.803-812, 2012. https:// doi.org/10.1016/j.chemosphere.2011.12.082

BOTTON, M.; NAVA, D.E.; ARIOLI, C.J.; GRÜTZMACHER, A.D., GARCIA, M.S. Bioecologia, monitoramento e controle da mariposa-oriental na cultura do pessegueiro no Rio Grande do Sul. Bento Gonçalves: Embrapa Uva e Vinho (CNPUV), 2011. 11 p. (Circular Técnica 86).

CASTILHOS, R.V.; GRÜTZMACHER, A.D.; NAVA, D.E.; ZOTTI, M.J.; SIQUEIRA, P.R.B. Seletividade de agrotóxicos utilizados em pomares de pêssego a adultos do predador Chrysoperla externa (Hagen, 1861) (Neuroptera: Chrysopidae). Revista Brasileira de Fruticultura, Jaboticabal, v.33, n.1, p.73-80, 2011 a. http:// dx.doi.org/10.1590/SO100-29452011005000042

CASTILHOS, R.V.; SIQUEIRA, P.R.B.; MORAES, I.L.; GRÜTZMACHER, A.D. Toxicidade de inseticidas registrados na cultura do pessegueiro sobre adultos do predador Chrysoperla externa (Hagen, 1861) (Neuroptera: Chrysopidae). In: ENCONTRO DE PÓS GRADUAÇÃO, 13., 201 1b. Pelotas. Anais.... Pelotas: UFPel, 201 1b. ref. CA 00092.

CASTILHOS, R.V.; GRÜTZMACHER, A.D.; NAVA, D. E.; ZOTTI, M.J.; SIQUEIRA, P.R.B.; SPAGNOL, D. Selectivity of pesticides used in peach orchards on the larval stage of the predator Chrysoperla externa (Hagen) (Neuroptera: Chrysopidae). Semina: Ciências Agrárias, Londrina, v. 34, n. 6, suplemento 1, p. 3585-3596, 2013.

CHAPMAN, J.W.; REYNOLDS, D.R.; BROOKS, S.J.; SMITH, A.D.; WOIWOD I.P. Seasonal variation in the migration strategies of the green lacewing Chrysoperla carnea species complex. Ecological Entomology, London, v.31, n.4, p.378-388, 2006. https://doi. org/10.1111/j.1365-2311.2006.00797.x

DESNEUX, N.; FAUVERGUE, X.; DECHAUME-MONCHARMONT, F.X.; KERHOAS, L.; BALLANGER, Y.; KAISER, L. Diaeretiella rapae limits Myzus persicae populations after applications of deltamethrin in oilseed rape. Journal of Economic Entomology, Annapolis, v.98, n. 1, p.9-17, 2005. https://doi.org/10.1093/jee/98.1.9

DESNEUX, N.; DECOURTYE, A.; DELPUECH, J.M. The sublethal effects of pesticides on beneficial arthropods. Annual Review of Entomology, Palo Alto, v.52, n. 1 p.81-106, 2007. https://doi. org/10.1146/annurev.ento.52.110405.091440
FREITAS, S. O uso de crisopídeos no controle biológico de pragas. In: PARRA, J.R.P.; BOTELHO, P.S.M.; CORRÊA-FERREIRA, B.S.; BENTO, J.M.S. (Eds.). Controle Biológico no Brasil: parasitóides e predadores. São Paulo: Manole, 2002. p.209-219.

GIOLO, F.P.; GRÜTZMACHER, A.D.; MANZONI, C.G.; FACHINELLO, J.C.; GRÜTZMACHER, D.D.; NÖRNBERG, S.D. Persistência de agrotóxicos indicados na produção integrada de pêssego a Trichogramma pretiosum Riley, 1879 (Hymenoptera: Trichogrammatidae). Revista Brasileira de Fruticultura, Jaboticabal, v.30, n. 1, p.122-126, 2008. http://dx.doi.org/10.1590/SO100-29452008000100023

GIOLO, F.P.; MEDINA, P.; GRÜTZMACHER, A.D.; VIÑUELA, E. Effects of pesticides commonly used in peach orchards in Brazil on predatory lacewing Chrysoperla carnea under laboratory conditions. BioControl, Darmstadt, v.54, n.5, p.625-635, 2009. http://dx.doi.org/10.1007/s10526-008-9197-2

GRÜTZMACHER, A.D.; ZIMMERMANN, O.; YOUSSEF, A.; HASSAN, S.A. The side-effects of pesticides used in integrated production of peaches in Brazil on the egg parasitoid Trichogramma cacoeciae Marchal (Hymenoptera: Trichogrammatidae). Journal of Applied Entomology, Goettingen, v.128, n.6, p.377-383, 2004. http:// dx.doi.org/10.1111/j.1439-0418.2004.00800.x

GRÜTZMACHER, A.D.; CASTILHOS, R.V.; SIQUEIRA, P.R.B.; MORAES, I.L.; GAUER, C.J. Efeito de inseticidas registrados para a cultura do pessegueiro sobre larvas de Chrysoperla externa (Hagen, 1861 ) (Neuroptera: Chrysopidae). In: SIMPÓSIO DE CONTROLE BIOLÓGICO, 12., 2011 , São Paulo. Anais... São Paulo: Instituto Biológico, 2011 . ref. CO.02.12

HEUER, B.; BIRK, Y.; YARON, B. Effect of phosphatases on the persistence of organophosphorus insecticides in soil and water. Journal of Agricultural and Food Chemistry, Washington, v.24, n.3, p.611-614,1976. https://doi.org/10.1021/jf60205a028

KRALJ, M.B.; FRANCO, M.; TREBSE, P. Photodegradation of organophosphorus insecticides - Investigations of products and their toxicity using gas chromatography-mass spectrometry and AChE-thermal lens spectrometric bioassay. Chemosphere, Amsterdam, v.67, n.1, p.99-107, 2007. https://doi. org/10.1016/j.chemosphere.2006.09.039

MACHADO, A.; CONCEIÇÃO, A.R. WinStat: sistema de análise estatístico para Windows. Versão 2.0. Pelotas: UFPel, 2007.

MAIA, J.B.; CARVALHO, G.A.; MEDINA, P.; GARZÓN, A.; GONTIJO, P.C.; VIÑUELA, E. Lethal and sublethal effects of pesticides on Chrysoperla carnea larvae (Neuroptera: Chrysopidae) and the influence of rainfastness in their degradation pattern over time. Ecotoxicology, New York, v.25, n.5, p.845-855, 2016. https:// doi.org/10.1007/s10646-016-1641-y 
MANSOOR, M.M.; AFZAL, M.; RAZA, A.B.M.; AKRAM, Z.; WAQAR, A.; AFZAL, M. B.S. Post-exposure temperature influence on the toxicity of conventional and new chemistry insecticides to green lacewing Chrysoperla carnea (Stephens) (Neuroptera: Chrysopidae). Saudi Journal of Biological Sciences, Riyadh, v.22, n.3, p.317-321, 2015. https://doi.org/10.1016/j.sjbs.2014.10.008

NIENSTEDT, K.M.; MILES, M. Aged-residue method for evaluating toxicity of plant protection products to Stethorus punctillum (Weise) (Coleoptera: Coccinellidae). IOBC/WPRS Bulletin, Darmstadt, v.35, p.122-127, 2008.

NÖRNBERG, S.D.; GRÜTZMACHER, A.D.; KOVALESKI, A.; FINATTO, J.A.; PASCHOAL, M.D.F. Persistência de agrotóxicos utilizados na produção integrada de maçã a Trichogramma pretiosum. Ciência e Agrotecnologia, Lavras, v.35, n.2, p.305-313, 2011 . http:// dx.doi.org/10.1590/S1413-70542011000200011

PARRA, J.R.P.; COELHO JUNIOR, A. Applied biological control in Brazil: from laboratory assays to field application. Journal of Insect Science, Oxford, v.19, n.2, p.1-6, 2019. https://doi. org/10.1093/jisesa/iey 112

PALMQUIST, K.; SALATAS, J.; FAIRBROTHER, A. Pyrethroid insecticides: use, environmental fate, and ecotoxicology, In: PERVEEN, F. (Ed.). Insecticides - Advances in integrated pest management. Rijeka: InTech, 2012. p.251-278.

PEKÁR, S.; BENEŠ, J. Aged pesticide residues are detrimental to agrobiont spiders (Araneae). Journal of Applied Entomology, Goettingen, v.132, n.8, p.614-622, 2008. https://doi. org/10.1111/j.1439-0418.2008.01294.x

PÜNTENER, W. Manual for field trials in plant protection. 2. ed. Greensboro: Ciba-Geigy, 1981. 205p.

RUIZ, M.G.; MORAES, G.J. Mortalidade do ácaro predador Neoseiulus californicus (Acari: Phytoseiidae) em testes de toxicidade residual de inseticidas e acaricidas usuais em pomáceas. Revista Brasileira de Fruticultura, Jaboticabal, v.30, n.4, p.919-924, 2008. http:// dx.doi.org/10.1590/SO100-29452008000400014

ROUBOS, C.R.; RODRIGUEZ-SAONA, C.; HOLDCRAFT, R.; MASON, K.S.; ISAACS, R. Relative toxicity and residual activity of insecticides used in blueberry pest management: Mortality of natural enemies. Journal of Economic Entomology, Annapolis, v. 107, n. 1, p.277-285, 2014. https://doi.org/10.1603/ec13191

SCHUBER, J.M.; MONTEIRO L.B.; POLTRONIERI, A.S.; CARDOSO, N.A.; MAY DE MIO, L.L. Influência de sistemas de produção sobre a ocorrência de inimigos naturais de afídeos em pomares de pessegueiros em Araucária-PR. Revista Brasileira de Fruticultura, Jaboticabal, v.30, n.2, p.336-342, 2008. http://dx.doi. org/10.1590/SO100-29452008000200012

SILVA, M.Z.; OLIVEIRA, C.A.L. Toxicidade residual de alguns agrotóxicos recomendados na citricultura sobre Neoseiulus californicus (Mcgregor) (Acari: Phytoseiidae). Revista Brasileira de Fruticultura, Jaboticabal, v.29, n.1 p.85-90. 2007. http:// dx.doi.org/10.1590/SO100-29452007000100019
SISTEMA DE AGROTÓXICOS FITOSSANITÁRIOS (AGROFIT). Consulta de Produtos Formulados. Available from: <http://agrofit. agricultura.gov.br/agrofit_cons/!ap_produto_form_consulta_ cons>. Access on: Nov. 232017.

SOARES, J.J.; CORDÃO SOBRINHO, F.P.; MELO, R.S.; FERREIRA, A.M.C.; ALMEIDA, C.A. Predação de Chrysoperla externa sobre diferentes presas. Campina Grande: Embrapa Algodão, 2003. 3p. (Comunicado Técnico 174).

STARK J.D.; VARGAS, R.; BANKS, J.E. Incorporating ecologically relevant measures of pesticide effect for estimating the compatibility of pesticides and biocontrol agents. Journal of Economic Entomology, Annapolis, v.100, n.4, p.1027-1032, 2007. https://doi. org/10.1603/0022-0493(2007)100[1027:iermop]2.0.co;2

STEFANELLO JÚNIOR, G.J.; GRÜTZMACHER, A.D.; SPAGNOL, D.; PASINI, R.A.; BONEZ, C.; MOREIRA, D.C. Persistência de agrotóxicos utilizados na cultura do milho ao parasitoide Trichogramma pretiosum Riley, 1879 (Hymenoptera: Trichogrammatidae). Ciência Rural, Santa Maria, v.42, n.1, p.17-23, 2012. http:// dx.doi.org/10.1590/SO103-84782012000100004

TUNAZ, H.; UYGUN, N. Insect growth regulators for insect pest control. Turkish Journal of Agriculture and Forestry, Ankara, v.28, n.6, p.377-387. 2004.

VAN DE VEIRE, M.; STERK, G.; VAN DER STAAIJ, M.; RAMAKERS, P.M.J.; TIRRY, L. Sequential testing scheme for the assessment of the side-effects of plant protection products on the predatory bug Orius laevigatus. BioControl, Darmstadt, v.47, n.1, p.101-113, 2002. https://doi.org/10.1023/A: 1014473023912

VANACLOCHA, P.; VIDAL-QUIST, C.; OHEIX, S.; MONTÓN H.; PLANES L.; CATALÁN, J.; TENA, A.; VERDU, M.J.; URBANEJA, A. Acute toxicity in laboratory tests of fresh and aged residues of pesticides used in citrus on the parasitoid Aphytis melinus. Journal of Pest Science, Innsbruck, v.86, n.2, p.329-336, 2013. https://doi.org/10.1007/s10340-012-0448-8

VOGT H.; DEGRANDE P.; JUST, J.; KLEPKA, S.; KUHNER, C.; NICKLESS, A.; UFER, A.; WALDBURGER, M.; WALTERSDORFER, A.; BIGLER, F. (1998) Side-effects of pesticides on larvae of Chrysoperla carnea (Neuroptera, Chrysopidae): actual state of the laboratory method. In: HASKELL, P.T.; MCEWEN, P. (Eds.). Ecotoxicology. Boston: Springer, 1998. p.123-136.

VOGT H.; BIGLER, F.; BROWN, K.; CANDOLFI, M.P.; KEMMETER, F.; KÜHNER, C.; MOLL, M.; TRAVIS, A.; UFER, A.; VIÑUELA, E.; WLADBURGER, M.; WALTERSDORFER, A. Laboratory method to test effects of plant protection products on larvae of Chrysoperla carnea (Neuroptera: Chrysopidae). In: CANDOLFI, M.P.; BLUMEL, S.; FORSTER, R.; BAKKER, F.M.; GRIMM, C.; HASSAN, S.A.; HEIMBACH, U.; MEAD-BRIGGS, M.A.; REBER, B.; SCHMUCK, R.; VOGT, H. (Eds.). Guidelines to evaluate side-effects of plant protection products to non-target arthropods. Reinheim: IOBC/WPRS, 2000. p.27-44.

ZONGMAO, C.; HAIBIN, W. Degradation of pesticides on plants surface and its prediction - A case study on tea plant. Environmental Monitoring and Assessment, Orono, v.44, n.1/3, p.303-313, 1997. 